$$
634.6109631 .8 \%: 99
$$

\title{
Studies On Potassium Magnesium Interaction In Coconut (Cocos nucifera)
}

\author{
M. JEGANATHAN
}

\section{Coconut Research Institute, Lunuwila, Sri Lanka}

Key words: Coconut, Cocos nucifera L., copra, leaf analysis, nut water analysis, ultisol

\begin{abstract}
The widespread deficiency of magnesium in coconut acts as a limiting factor to increased production. Two ongoing experiments on potassium-magnesium $(\mathrm{K}-\mathrm{Mg})$ interaction in coconut conducted in lateritic gravels (ultisols), in the wet and intermediate agroclimatic zones of Sri Lanka showed significant yield responses $(\mathrm{P}=0.01)$ to differential $\mathrm{K}$ treatments, in the wet zone, but not in the intermediate zone. Differential $\mathrm{Mg}$ treatments, however, did not give rise to yield responses. Leaf and nut water analysis showed significant changes in the concentrations of $\mathrm{Na}, \mathrm{K}$ and $\mathrm{Cl}(\mathrm{P}=0.001)$, with a distinct inverse relationship between $\mathrm{Na}$ and $\mathrm{K}$ when $\mathrm{K}$ was applied. Differential $\mathrm{Mg}$ applications showed a significant effect only for leaf $\mathrm{Mg}(\mathrm{P}=0.001)$, in the fourth year of the experiment, in the wet zone. Results indicate the usefulness of nut water analysis as an additional diagnostic tool, for $\mathrm{Na}, \mathrm{K}$ and $\mathrm{Cl}$.
\end{abstract}

\section{INTRODUCTION}

In the plantation agriculture in Sri Lanka, coconut (Cocos nucifera L.) occupies the highest area of nearly 420,000 ha. The estate sector ( 8 ha or more) comprises 104,000 ha $(24.7 \%)$ of the area while the balance, 316,000 ha $(75.3 \%)$ is categorized as small holdings.

Coconut is a very important commodity in Sri Lanka. It is used traditionally as a component in food, and about $70 \%$ of the production is consumed locally. About $9 \%$ of the total expenditure on food of an average household is spent on coconut, the principal source of edible oil and fat. Coconut provides about $22 \%$ of the total intake of calories of an average consumer in Sri Lanka second to rice. These data amply demonstrate the importance of coconut.

In order to meet the high domestic consumption and also maintain the export market, increased production can be achieved with regular and increased fertilization.

Reprinted from Plant Nutrition - Physiology and Applications (1990) with kind permission of Kluwer Academic Publishers. 
Potassium is the most important nutrient for the production of nuts and copra, the latter used in oil extraction. Although the importance of $\mathrm{K}$ nutrition has been experimentally shown (Loganathan and Balakrishnamurthi, 1979; Salgado. 1950) widespread occurrence of $\mathrm{Mg}$ deficiency in the lateritic and the sandy soils has been a limiting factor in coconut production. It is necessary therefore to study the limitations in the use of high levels of $\mathrm{K}$ obviously due to $\mathrm{K}-\mathrm{Mg}$ interactions and their antagonistic effects. This paper describes results of two experiments conducted to elucidate this aspect in coconut nutrition with a view to determine levels of $\mathrm{Mg}$ in the soil and leaf for more effective $\mathrm{K}$ usage.

\section{MATERIALS AND METHODS}

Two experiments were conducted on adult tall coconut (variety typica) of age about 55 years, in 7 and 14 hectare blocks, at Sirikandura Estate, Dodanduwa (Southern Province) and at Heemmeliyagara Estate, Hiruwalpola (North Western Province), from October 1984.

Sirikandura Estate (SE) falls in the wet zone receiving an annual rainfall of 1875 to 2500 $\mathrm{mm}$. while Heemmeliyagara Estate $(\mathrm{HE})$ is in the intermediate zone receiving an annual rainfall of 1000 to $1875 \mathrm{~mm}$. The rainfall is bimodal, with peaks in April/June and October/November. The soils in both experimental sites are Red Yellow Podzolic with soft and hard laterite (Ultisols).

The chemical characteristics of the soils are given in Table 1.

\section{Design and treatments}

The experimental design consisted of a $4 \times 4$ factorial arrangement for the two nutrients $\mathrm{K}$ and $\mathrm{Mg}$ in three blocks, each consisting of 16 plots of eight effective palms separated by a single row of guard trees. The planting density is 158 palms/ha.

Fertilizer applications were made annually starting in 1984, as follows:

\begin{tabular}{|c|c|c|c|}
\hline \multicolumn{2}{|c|}{$\begin{array}{l}\text { Muriate of Potash } \\
(60 \% \mathrm{~K} 2 \mathrm{O}) \\
\mathrm{kg} / \mathrm{palm} / \mathrm{yr}\end{array}$} & \multicolumn{2}{|c|}{$\begin{array}{l}\text { Kieserite } \\
(24 \% \mathrm{MgO}) \\
\mathrm{kg} / \mathrm{palm} / \mathrm{yr}\end{array}$} \\
\hline $\mathrm{K} 1$ & 0.0 & $\mathrm{Mg} 1$ & \\
\hline $\mathrm{K} 2$ & 1.2 & $\mathrm{Mg} 2$ & \\
\hline K3 & 2.4 & Mg3 & 1.2 \\
\hline K4 & 3.6 & $\mathrm{Mg} 4$ & 1.8 \\
\hline
\end{tabular}

Basal applications of urea and rock phosphate, each at the rate of $0.7 \mathrm{~kg} / \mathrm{palm} / \mathrm{yr}$, equivalent to $0.32 \mathrm{~kg} \mathrm{~N}$ and $0.19 \mathrm{~kg} \mathrm{P}_{2} \mathrm{O}_{5}$, were made in all treatments.

At SE, only the first three levels of treatment were imposed. The fertilizer was applied on the surface of a circular area with a radius of $1.75 \mathrm{~m}$, around the base of the palm, and incorporated into the soil using a fork. 


\section{Soil and leaf sampling}

Four palms were chosen randomly from each plot. In these palms, the 14 th leaf from the top, the $1^{\text {st }}$ being the fully opened leaf with its leaflets separated, was selected and six leaflets were taken from the mid region and composited to form a sample, oven-dried at $85{ }^{\circ} \mathrm{C}$ and ground for analysis.

Soil samples were collected from the manure circle. Two borings were made at $1 \mathrm{~m}$ from the base on either side of the palms and samples were collected from two depths, 0-25 cm, and $25-50 \mathrm{~cm}$ and composited separately.

\section{Nut water analysis}

Nut water or 'coconut water' is the colourless liquid found within the hard white kernel (the solid endosperm), both of which are enclosed by the hard shell. From each plot, eight nuts representing each of the palms, selected at random, were sampled and the nut water from them was mixed well, filtered and aliquots were taken for analysis.

\section{Chemical analysis}

For soil analysis a $1 \mathrm{M} \mathrm{CH}_{3} \mathrm{COONH}_{4}$ extractant was used for the extraction of exchangeable $\mathrm{Na}, \mathrm{K}, \mathrm{Ca}$ and $\mathrm{Mg}$ and determined by atomic absorption, $\mathrm{Na}$ and $\mathrm{K}$ in the emission and $\mathrm{Ca}$ and $\mathrm{Mg}$ in the absorption modes. $\mathrm{Cl}$ was read off the Chlor-O-Counter after extraction in 1:1 soil water ratio.

For leaves, $\mathrm{N}$ was determined in 0.1 -g samples digested in $\mathrm{Se} / \mathrm{H}_{2} \mathrm{SO}_{4}$ mixture, and $\mathrm{P}, \mathrm{Na}$, $\mathrm{K}, \mathrm{Ca}$ and $\mathrm{Mg}$, in $0.5 \mathrm{~g}$ samples digested in $\mathrm{HNO}_{3} / \mathrm{HCLO}_{4}$ mixture. $\mathrm{N}$ and $\mathrm{P}$ were estimated colorimetrically on a Technicon Auto Analyzer and $\mathrm{Na}, \mathrm{K}, \mathrm{Ca}$ and $\mathrm{Mg}$, as for soils, by atomic absorption. $\mathrm{Cl}$ was determined in $2.0 \mathrm{-g}$ samples, ashed in a muffle furnace at $450^{\circ} \mathrm{C}$, extracted with water and read off the Chlor-O-Counter.

Nut water was analysed by diluting 20 times for $\mathrm{Na}$ and $\mathrm{K}$, and 100 times for $\mathrm{Ca}$ and $\mathrm{Mg}$ and read off the Atomic Absorption Spectrophotometer (Somasiri et al.., 1986). Cl was estimated on the Chlor-O-Counter, using $0.1 \mathrm{ml}$ of nut water (Periathamby, personal. communication).

\section{Yield}

Commencing January 1985, ripe nuts were harvested from the two mature bunches bimonthly and the total number of nuts recorded. Weights of the husked nuts were obtained from samples of 32 nuts representing each treatment. The yield of copra was determined using the 'copra index factor' (Mathes, 1985 - personal communication). 


\section{RESULTS AND DISCUSSION}

\section{Soils and leaf analysis - Pretreatment data}

The pretreatment soil analytical data in Table 1 show the exchangeable cations in the manure circle higher than in the centres of squares. This is due to the residual fertility in the manure circle, while the centre of squares reflects the inherent fertility.

Table 1 - Soil analysis - October 1984

\begin{tabular}{|c|c|c|c|c|}
\hline \multirow[t]{2}{*}{ Parameters } & \multicolumn{2}{|c|}{$\begin{array}{c}\text { Sirikandura Estate } \\
\text { Depth }\end{array}$} & \multicolumn{2}{|c|}{$\begin{array}{c}\text { Heemmeliyagara Estate } \\
\text { Depth }\end{array}$} \\
\hline & $0.25 \mathrm{~cm}$ & $25-50 \mathrm{~cm}$ & $0-25 \mathrm{~cm}$ & $25.50 \mathrm{~cm}$ \\
\hline \multicolumn{5}{|c|}{ Chemical parameters of pretreatment samples in the fertilized circle } \\
\hline $\mathrm{pH}$ & 4.2 & 3.8 & 5.5 & 5.1 \\
\hline E.C (mmhos/cm) & 51.39 & 55.25 & 46.88 & 52.26 \\
\hline Exch. $\mathrm{Na}(\mathrm{meq} \%)$ & 0.08 & 0.06 & 0.08 & 0.10 \\
\hline Exch. $K(\mathrm{meq} \%)$ & 0.26 & 0.16 & 0.30 & 0.44 \\
\hline Exch. Ca (meq\%) & 1.27 & 0.59 & 1.56 & 1.04 \\
\hline Exch. Mg (meq\%) & 0.20 & 0.16 & 0.57 & 0.38 \\
\hline Avail. Cl (mg/kg) & 27.62 & 27.30 & 24.01 & 30.08 \\
\hline \multicolumn{5}{|c|}{ Outside the fertilized circle, in the centre of square formed by four palms } \\
\hline $\mathrm{pH}$ & 4.0 & 3.9 & 5.0 & 5.0 \\
\hline E.C $(\mathrm{mmhos} / \mathrm{cm}$ & 33.39 & 21.75 & 36.08 & 16.34 \\
\hline Exch. $\mathrm{Na}(\mathrm{meq} \%)$ & 0.03 & 0.03 & 0.07 & 0.08 \\
\hline Exch. K (meq\%) & 0.08 & 0.04 & 0.13 & 0.10 \\
\hline Exch. Ca (meq\%) & 1.06 & 0.31 & 0.73 & 0.65 \\
\hline Exch. $\mathrm{Mg}(\mathrm{meq} \%)$ & 0.20 & 0.16 & 0.42 & 0.40 \\
\hline Avail. $\mathrm{Cl}$ (mg/kg) & 18.94 & 20.40 & 16.06 & 14.33 \\
\hline
\end{tabular}

The mean exchangeable $\mathrm{K}$ level in the manure circles of the two sites at the first depth was $0.28 \mathrm{meq} \%$. Earlier experiments in lateritic soils in the wet zone have shown that in spite of such high $\mathrm{K}$ levels in the soil, the palms responded to muriate of potash (Loganathan and Balakrishnamurti, 1979). In the sub-soil $(25-50 \mathrm{~cm})$ the exchangeable $\mathrm{K}$ was much lower at SE than at $\mathrm{HE}, 0.16$ and $0.44 \mathrm{meq} \%$, respectively, which is probably due to leaching losses resulting from higher rainfall in the wet zone.

Information available on exchangeable $\mathrm{Mg}$ is scanty. Ollagnier et al., (1983) considered an exchangeable $\mathrm{Mg}$ level of $0.46 \mathrm{meq} \%$ as high. The critical values for exchangeable $\mathrm{K}$, and $\mathrm{Mg}$ in the Philippines are 0.45, and $2.9 \mathrm{meq} \%$, respectively (Santiago, 1978). Margate et al. (1979) did not observe a $\mathrm{K}-\mathrm{Mg}$ antagonism in a long-term $\mathrm{KCl}$ fertilizer study on a clay loam 
soil in the Philippines in spite of high application of $\mathrm{KCl}(8 \mathrm{~kg} / \mathrm{palm} / \mathrm{year})$, with soil levels of $0.45 \mathrm{meq} \% \mathrm{~K}$ and $5.3 \mathrm{meq} \% \mathrm{Mg}$. On this basis, the soils in SE are not rich.

The data in Table 2 show the average concentrations of nutrients in the 14th leaf. With the exception of $\mathrm{K}$ in both locations and $\mathrm{Mg}$ at $\mathrm{SE}$, the levels of the other nutrients fall within the sufficiency ranges as described by Loganathan and Atputharaja (1986).

Table 2 Pretreatment leaf nutrient concentrations (14th leaf) on the Sirikandura and Heemeliyagara Estates

Nutrients (\% in dry weight)

\begin{tabular}{lcccccc}
\hline & $\mathrm{N}$ & $\mathrm{P}$ & $\mathrm{K}$ & $\mathrm{Ca}$ & $\mathrm{Mg}$ & $\mathrm{CI}$ \\
\hline & & & & & & \\
Sirikandura & 2.02 & 0.15 & 1.09 & 0.38 & 0.16 & 0.30 \\
Heemmeliyagara & 1.98 & 0.15 & 1.10 & 0.50 & 0.30 & 0.34 \\
$\begin{array}{l}\text { Sufficiency } \\
\text { ranges }\end{array}$ & $1.9-2.1$ & $0.11-0.13$ & $1.2-1.5$ & $0.35-0.55$ & $0.25-0.30$ & $0.30-0.40$ \\
\hline
\end{tabular}

Sirikandura Estate Analysis of leaf samples collected in May 1988 (Table 3) showed that the concentrations of both $\mathrm{N}$ and $\mathrm{P}$ had remained unaltered by the differential treatments.

Applications of $\mathrm{K}$ showed significant quadratic responses in leaf $\mathrm{K}$ and $\mathrm{Mg}$, a significant linear increase in $\mathrm{Cl}$ and decrease in $\mathrm{Na}$ and $\mathrm{Ca}$.

Increasing rates of $\mathrm{Mg}$ applied showed a highly significant linear increase for $\mathrm{Mg}$ only in 1988 , the fourth year of the experiment.

At $\mathrm{SE}$ leaf $\mathrm{K}$ reached the value of $1.49 \%$ from the premanurial $1.09 \%$ at the highest level, $\mathrm{K} 3(2.4 \mathrm{~kg} / \mathrm{palm} / \mathrm{year})$, a significant improvement in $\mathrm{K}$ nutrition. Increasing applications of $\mathrm{Mg}$ caused significant increases in leaf $\mathrm{Mg}$, from the premanurial $0.16 \%$, to $0.22 \%$ at the $\mathrm{Mg} 3$ level $(1.2 \mathrm{~kg} / \mathrm{palm} / \mathrm{year})$ still below the critical concentration of $0.25 \%$.

Hemmeliyagara Estate As at $\mathrm{SE}$, both $\mathrm{N}$ and $\mathrm{P}$ remained unaffected by the differential $\mathrm{K}-\mathrm{Mg}$ treatments (Table 4).

Increasing rates of $\mathrm{K}$ applied showed significant linear increase in leaf $\mathrm{K}$ and decreases in leaf $\mathrm{Na}$ and $\mathrm{Mg}$. $\mathrm{Cl}$ showed a linear response.

From the pretreatment $1.10 \%$ level, leaf $\mathrm{K}$ increased to only $1.12 \%$ at $\mathrm{K} 4$, still below the critical level of $1.2 \%$. Unlike at $\mathrm{SE}$, increasing rates of $\mathrm{Mg}$ caused no changes in any nutrient levels. 
Table 3. Leaf nutrient concentrations after four years of differential $K$ and $M g$ applications, at Sirikandura Estate - May 1988

\section{Concentration of nutrients (\% in 14 th leaf)}

\begin{tabular}{|c|c|c|c|c|c|c|c|}
\hline Treatment & $N$ & $P$ & $\mathrm{Na}$ & $K$ & $\mathrm{Ca}$ & $M g$ & $\mathrm{Cl}$ \\
\hline $\mathrm{K} 1$ & 2.27 & 0.156 & 0.30 & 0.63 & 0.50 & 0.27 & 0.37 \\
\hline $\mathrm{K} 2$ & 2.38 & 0.158 & 0.25 & 1.18 & 0.41 & 0.15 & 0.49 \\
\hline K3 & 2.36 & 0.156 & 0.21 & 1.49 & 0.40 & 0.15 & 0.56 \\
\hline Mg1 & 2.32 & 0.157 & 0.26 & 1.14 & 0.43 & 0.15 & 0.49 \\
\hline Mg2 & 2.34 & 0.158 & 0.25 & 1.09 & 0.45 & 0.20 & 0.45 \\
\hline Mg3 & 2.35 & 0.157 & 0.24 & 1.07 & 0.43 & 0.22 & 0.47 \\
\hline \multicolumn{8}{|l|}{ Sign level } \\
\hline K I & - & - & $* *$ & $* * \star$ & ** & $* * *$ & $* * *$ \\
\hline $\mathrm{K} \quad \mathrm{q}$ & - & - & - & ** & $\cdot$ & ** & - \\
\hline $\mathrm{Mg} 1$ & - & - & $\cdot$ & - & - & $* * *$ & - \\
\hline CV\% & 3.55 & 2.81 & 11.89 & 7.76 & 9.24 & 9.41 & 9.20 \\
\hline
\end{tabular}

$* \mathrm{P}=0.05, * * \mathrm{P}=0.01 ; * * * \mathrm{P}=0.001$

Table 4. Leaf nutrient concentrations due to differential applications of $K$ and $M g$ at Heemmeliyagara Estate -January 1988

\section{Concentration of nutrients (\% in 14 th leaf)}

\begin{tabular}{cccccccc} 
Treatment & $N$ & $P$ & $N a$ & $K$ & $C a$ & $M g$ & $C l$ \\
\hline K1 & 2.14 & 0.128 & 0.15 & 0.83 & 0.56 & 0.35 & 0.35 \\
K2 & 2.13 & 0.129 & 0.12 & 0.99 & 0.51 & 0.32 & 0.46 \\
K3 & 2.13 & 0.130 & 0.11 & 1.04 & 0.45 & 0.29 & 0.49 \\
K4 & 2.11 & 0.130 & 0.10 & 0.12 & 0.50 & 0.27 & 0.52 \\
& & & & & & & \\
Mg1 & 2.13 & 0.131 & 0.12 & 0.98 & 0.52 & 0.30 & 0.46 \\
Mg2 & 2.11 & 0.129 & 0.13 & 1.00 & 0.52 & 0.31 & 0.46 \\
Mg3 & 2.16 & 0.129 & 0.11 & 1.00 & 0.50 & 0.32 & 0.43 \\
Mg4 & 2.11 & 0.128 & 0.12 & 1.00 & 0.50 & 0.32 & 0.48 \\
Sign. level & & & & & & & \\
K I & - & - & $* * *$ & $* * *$ & $*$ & $* *$ & $* *$ \\
K q & - & - & - & - & $*$ & - & - \\
CV\% & 6.21 & 21.77 & 12.89 & 14.95 & 14.95 & 11.75 & 22.70 \\
\hline
\end{tabular}

$* \mathrm{P}=0.05 ; * * \mathrm{P}=0.01 ; * * * \mathrm{P}=0.001$ 


\section{Nut water analysis}

Sirikandura Estate Analysis of the nut water collected in March 1988 (Table 5) showed responses to increasing rates of $\mathrm{K}$ and $\mathrm{Mg} . \mathrm{K}$ application caused highly significant positive responses, both linear and quadratic, in the uptake of $\mathrm{K}$ and $\mathrm{Cl}$, and a negative response for $\mathrm{Na}$. $\mathrm{Mg}$ application only caused a significant linear increase in $\mathrm{Cl}$, which is unusual and difficult to explain.

Heemmeliyagara Estate $\mathrm{As}$ at $\mathrm{SE}$, negative linear and quadratic responses of $\mathrm{Na}$ to increasing $\mathrm{K}$ applications were observed (Table 6). $\mathrm{K}$ and $\mathrm{Mg}$ showed significant responses, both linear and quadratic, to increasing rates of $\mathrm{K}$. Increased application of $\mathrm{Mg}$ caused a linear increase in $K$, which was unexpected, in view of the fact that usually these two nutrients show antagonistic effects.

In Sri Lanka, chemical analysis of nut water has been successfully used in the study of $P$ and $\mathrm{K}$ nutrition of coconut (Salgado, 1955; 1966). In other countries this approach has also been used with some measure of success (Lockhard et al.., 1969, Southern, 1956).

Present indications are that nut water analysis can be used as an additional tool in the interpretation of field experiment data for $\mathrm{Na}, \mathrm{K}, \mathrm{Mg}$ and $\mathrm{Cl}$. Both $\mathrm{Ca}$ and $\mathrm{Mg}$ have functionally limited roles to perform, both in the liquid and in the solid endosperm, and therefore their concentration will be low and so too the changes.

\section{Yield}

Sirikandura Estate Analysis of the second year's data (1986) showed a significant response in terms of copra production at $(\mathrm{P}=0.01)$ to increasing $\mathrm{K}$ applications. For the years 1987 and 1988, these responses were highly significant at $P=0.001$ (Table 7). Nut yields also significantly increased during these two years as a result of $\mathrm{K}$ application (Table 8).

There has been an overall decrease in yield of copra, despite the increased application of K. The drop in the 'no fertilizer' plots has been drastic, 32.4\% between 1986 and 1988 . During the same period, at the $\mathrm{K} 1$ and $\mathrm{K} 2$ levels, the decreases have been $17.2 \%$ and $14.6 \%$, respectively. Fertilizer application has to some extent arrested the decline. The fall in production can be attributed to adverse weather conditions, to the insufficient state of nutrition of the palms and to the low soil nutrient status. Table 9 gives the rainfall and yield data for the 'no fertilizer' plots at both sites. At SE, rainfall was high, except for 1986. The lower rainfall in 1986 was compensated for by a better distribution and therefore yields were not adversely affected in 1987.

From the nutritional aspects, it was observed that with all $\mathrm{K}$ application levels the $\mathrm{K}$ demand of the trees has been satisfied, and it is yet to be seen whether better yields will be obtained when the $\mathrm{Mg}$ concentrations reach the sufficiency level. It is only after $\mathrm{K}$ deficiency has been corrected that $\mathrm{Mg}$ manuring was found to have a positive effect on production (Brunin, 1970; Coomans, 1977). 
Table 5 Nut water nutrient concentrations after four years of differential application of $K$ and $\mathrm{Mg}$ at Sirikandura Estate-March 1988

$$
\text { Nutrient }\left(m g l^{-1}\right)
$$

Treatment

$\mathrm{Na}$

K

$\mathrm{Ca}$

$\mathrm{Mg}$

$\mathrm{Cl}$

\begin{tabular}{|c|c|c|c|c|c|}
\hline K1 & 270 & 1634 & 186 & 101 & 1870 \\
\hline $\mathrm{K} 2$ & 139 & 2375 & 171 & 105 & 2095 \\
\hline K3 & 91 & 2627 & 180 & 99 & 2102 \\
\hline Mg1 & 179 & 2195 & 185 & 100 & 2073 \\
\hline Mg2 & 167 & 2238 & 179 & 101 & 2038 \\
\hline $\mathrm{Mg} 3$ & 154 & 2202 & 174 & 105 & 1956 \\
\hline \multicolumn{6}{|c|}{ Sign. level } \\
\hline$\vec{K} \quad \mathrm{I}$ & *** & $\star \star \star \star$ & - & . & $* * *$ \\
\hline$k \quad q$ & $* *$ & $* * *$ & - & - & ** \\
\hline $\mathrm{Mg} \mathrm{I}$ & - & - & - & - & "* \\
\hline $\mathrm{CV} \%$ & 15.73 & 4.49 & 13.73 & 10.72 & 3.61 \\
\hline
\end{tabular}

$* \mathrm{P}=0.05 ; * * \mathrm{P}=0.01 ; * * * \mathrm{P}=0.01$

$\mathrm{l}=$ linear response, $\mathrm{q}=$ quadratic response

Table 6 Nut water nutrient concentrations after four years of differential application of $K$ and Mg at Heemmeliyagara Estate - March 1988.

\begin{tabular}{|c|c|c|c|c|c|}
\hline \multicolumn{6}{|c|}{ Nutrient (mg l-I) } \\
\hline Treatment & $\mathrm{Na}$ & $\mathrm{K}$ & $\mathrm{Ca}$ & $\mathrm{Mg}$ & $\mathrm{Cl}$ \\
\hline $\mathrm{K} 1$ & 140 & 1918 & 283 & 156 & 1959 \\
\hline $\mathrm{K} 2$ & 80 & 2128 & 278 & 138 & 1997 \\
\hline K3 & 71 & 2201 & 282 & 130 & 2012 \\
\hline $\mathrm{K} 4$ & 64 & 2196 & 301 & 142 & 2062 \\
\hline Mg1 & 96 & 1985 & 292 & 143 & 1983 \\
\hline Mg2 & 85 & 2120 & 303 & 143 & 2037 \\
\hline Mg3 & 90 & 2141 & 276 & 140 & 2027 \\
\hline $\mathrm{Mg} 4$ & 84 & 2197 & 272 & 141 & 1984 \\
\hline \multicolumn{6}{|l|}{ Sign. level } \\
\hline K I & $* *$ & $* * *$ & - & ** & - \\
\hline $\mathrm{K} \mathrm{q}$ & • & * & - & *** & - \\
\hline $\mathrm{Mg} \mathrm{I}$ & $\cdot$ & ** & - & - & - \\
\hline CV\% & 41.44 & 7.55 & 14.92 & 9.74 & 5.48 \\
\hline
\end{tabular}

$* \mathrm{P}=0.05 ; * * \mathrm{P}=0.01 ; * * * \mathrm{P}=0.001$

$l=$ linear response, $q=q u a d r a t i c$ response. 
Table 7. Weight of copra in different years following the start of differential annual applications of $K$ and $\mathrm{Mg}$ at Sirikandura Estate, with 158 palms per ha.

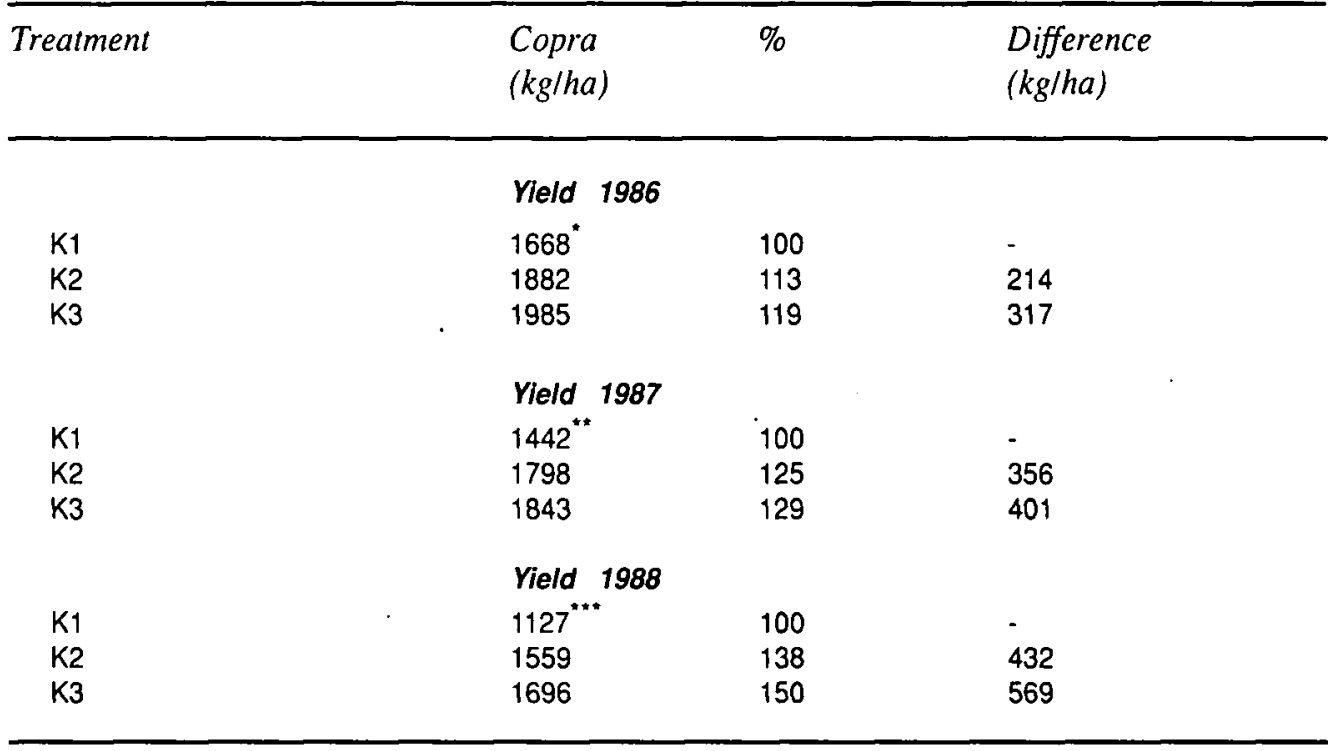

${ }^{*} \mathrm{P}=0.05 ;{ }^{* *} \mathrm{P}=0.01 ;{ }^{* * *} \mathrm{P}=0.001$

Table 8. Nut yield in different years following the start of differential annual applications of $K$ and $M g$ at Sirikandura Estate, with 158 palms per ha.

\begin{tabular}{|c|c|c|c|}
\hline Treatment & Nuts/ha & $\%$ & Difference \\
\hline & & 1986 & \\
\hline K1 & 8091 NS & 100 & - \\
\hline K2 & 8447 & 104 & 356 \\
\hline \multirow[t]{2}{*}{ K3 } & 8815 & 109 & 724 \\
\hline & & 1987 & \\
\hline $\mathrm{K} 1$ & $7433^{* *}$ & 100 & - \\
\hline K2 & 8545 & 115 & 1112 \\
\hline \multirow[t]{2}{*}{ K3 } & 8888 & 120 & 1455 \\
\hline & & 1988 & \\
\hline $\mathrm{K} 1$ & $5728^{* * *}$ & 100 & - \\
\hline K2 & 7290 & 127 & 1562 \\
\hline K3 & 7773 & 136 & 2045 \\
\hline
\end{tabular}

$$
\text { NS = Not Significant; }{ }^{*} \mathrm{P}=0.05 ;{ }^{* *} \mathrm{P}=0.01 ;{ }^{* * *} \mathrm{P}=0.001
$$




\section{JEGANATHAN}

Soil analysis data for the years 1987 and 1988 at the $\mathrm{Mg} 3$ application level yielded 0.73 and $0.63 \mathrm{meq} \% \mathrm{Mg}$, respectively. These fairly high exchangeable $\mathrm{Mg}$ levels in the soil can be expected to raise the $\mathrm{Mg}$ concentrations in the leaves enough to have a bearing on future production.

Heemmeliyagara Estate Statistical analysis of the yield data for the years 1986, 1987 and 1988 , in terms of nuts and copra, showed neither a significant response to the main treatments $\mathrm{K}$ and $\mathrm{Mg}$ nor to any interaction between them.

A combination of factors contributed to the lack of yield response, such as 'no fertilizer' plots performing much better than the others at the commencement of the studies (Table 9), and delayed application of fertilizers due to prolonged drought periods, compounded by the drought effect itself.

Table 9. Yield and rainfall data and corresponding nut and copra yield in the' no fertilizer' treatments at the two estates.

\begin{tabular}{|c|c|c|c|c|}
\hline Year & Ranfall & $\begin{array}{l}\text { No. of } \\
\text { wet days }\end{array}$ & Nuts/ha & $\begin{array}{l}\text { Copra } \\
(\mathrm{kg} / \mathrm{ha})\end{array}$ \\
\hline
\end{tabular}

Heemmeliyagara Estate

$\begin{array}{lcccc}1984 & 1815 & 87 & - & - \\ 1985 & 1262 & 55 & 11179 & 2074 \\ 1986 & 885 & 44 & 9263 & 1501 \\ 1987 & 1134 & 59 & 5649 & 751 \\ 1988 & 807 & 42 & 5267 & 898\end{array}$

Sirikandura Estate

\begin{tabular}{lllll}
1984 & 2240 & 133 & - & - \\
1985 & 2724 & 164 & 9381 & 1936 \\
1986 & 1990 & 174 & 8907 & 1783 \\
1987 & 2676 & 149 & 8117 & 1541 \\
1988 & 2505 & 137 & 6590 & 1249 \\
\hline
\end{tabular}

Changes in the concentrations of $\mathrm{Na}$ and $\mathrm{Cl}$ were observed in both leaf and nut water, resulting from differential fertilizer treatments. Both elements have some functions in the nutrition of coconut, particularly $\mathrm{Cl}$, but discussion of such functions is beyond the scope of this paper. 


\section{CONCLUSIONS}

Significant yield responses were obtained for the experiment at SE, albeit with an overall decrease in yield due to weather and nutritional factors. The experiment at HE failed to display any yield responses as a result of drought.

With respect of leaf and nut water analysis, in both experiments responses to the main treatments $\mathrm{K}$ and $\mathrm{Mg}$, were noticeable, with varying trends. Changes in the leaf composition was more pronounced at $\mathrm{SE}$ than at $\mathrm{HE}$.

Nut water analysis shows promise as an additional tool for interpretation of field experimental data.

The presentation covers a four-year period. Statistical studies on when to conclude longterm fertilizer trials on coconut yield consider an eight- to ten-year period as sufficient to understand the full response (Mathes, 1980). Both experiments are still in progress.

\section{ACKNOWLEDGEMENTS}

The author is thankful to Dr R Mahindapala, Director, Coconut Research Institute for helpful criticism in the preparation of the paper, and to Mr D T Mathes, Biometrician, Coconut Research Institute, for statistical advice and useful discussions.

Thanks are due to Miss S Periathamby, Mrs D M D I Wijebandara and Mr A A Fernando, for the maintenance of the laboratory and field records, and to the staff of the Soils and Plant Nutrition Division, Coconut Research Institute, for handling the analyses. Thanks are also due to Mrs H M W.S Athauda for typing the manuscript.

\section{REFERENCES}

Brunin C 1970 La nutrition magnesienne des cocoteraies en Cote d'Ivoire. Oleagineux 25, 269-274.

Coomans P 1977 Premiers resultats experimentaux sur la fertilisation des cocotiers hybrides en Cote d'ivoire. Oleagineux 32, 155-166.

Loganathan P and Balakrishnamurti T S 1979 Effect of N P K fertilizers on the yield and leaf nutrient concentration of adult coconut on a lateritic gravelly soil in Sri Lanka.

Ceylon Cocon. Q. 30, 81-90. 
Loganathan P and Atputharajah P P 1986 Effects of fertilizers on yield and leaf nutrient concentrations in coconut. Trop.Agric. Trindad 63, 143-148.

Lockard R G, Ballaux J C and Azucena B 1969 The results of pretreatment leaf and nut water analysis from ten coconut fertilizer experiments. Phil Agric. 53, 276-288.

Margate R Z, Magat S S, Alforja L M and Habana J A 1979 A long-term KCl fertilization study of bearing coconut in an inland upland area of Davao (Philippines). Oleagineux 34, 235-242.

Mathes D T 1980 A Study on when to conclude a long-term fertilizer trial on coconut yield. Ceylon Cocon. Q. 31, 127-133.

Ollagnier M, Ochs R, Pomier M and de Taffin G 1983 Effect of chlorine on the hybrid coconut PB 121 in the Ivory Coast and Indonesia. Oleagineux 38, 309-321.

Santigo R M 1978 Growth of coconut seedlings as influenced by different fertility levels in three soil types. Phil. J. Cocon. Stud. 3, 15-27.

Salgado M L M 1950 A. Rep. Coconut Research Scheme for 1948, Sessional paper XXII, Colombo Govt. Publications Bureau.

Salgado M L M 1955 The nutrient content of nut water in relation to available soil nutrients as a guide to the manuring of the coconut palms; a new diagnostic method. In Plant Analysis and Fertilizer Problems. Ed. P Prevot. pp 217-238. IRHO, Paris.

Salgado M L M and Abewardena V 1964 Nutritional and physiological studies on coconut water. Ceylon Cocon. Q. 15, 95-108.

Somasiri L L W, Warnasiri W H, George G D and Jeganathan M 1986 Report of the Soils and Plant Nutrition Division, Coconut Research Institute. Report for 1986, 87-88.

Southern P J 1956 The flame spectrophotometric determination of potassium, sodium, calcium and magnesium in nut water. Papua New Guinea Agric. J. 11, 69-76. 